\title{
Limpets counteract ocean acidification induced shell corrosion by thickening of aragonitic shell layers
}

\author{
G. Langer ${ }^{1}$, G. Nehrke ${ }^{2}$, C. Baggini ${ }^{3}$, R. Rodolfo-Metalpa ${ }^{4}$, J. M. Hall-Spencer ${ }^{3}$, and J. Bijma ${ }^{2}$ \\ ${ }^{1}$ Department of Earth Sciences, Cambridge University, Cambridge, UK \\ ${ }^{2}$ Biogeosciences, Alfred-Wegener-Institut Helmholtz-Zentrum für Polar- und Meeresforschung, Bremerhaven, Germany \\ ${ }^{3}$ School of Marine Science and Engineering, University of Plymouth, Plymouth, UK \\ ${ }^{4}$ CoRéUs, Institut de Recherche pour le Développement, Centre IRD de Noumea, Noumea, New Caledonia
}

Correspondence to: G. Langer (g1345@cam.ac.uk)

Received: 1 August 2014 - Published in Biogeosciences Discuss.: 25 August 2014

Revised: 6 November 2014 - Accepted: 9 November 2014 - Published: 20 December 2014

\begin{abstract}
Specimens of the patellogastropod limpet Patella caerulea were collected within $\left(\mathrm{pH}_{\mathrm{low}}\right.$-shells) and outside $\left(\mathrm{pH}_{\mathrm{n}}\right.$-shells) a $\mathrm{CO}_{2}$ vent site at Ischia, Italy. Four $\mathrm{pH}_{\mathrm{low}^{-}}$ shells and four $\mathrm{pH}_{\mathrm{n}}$-shells were sectioned transversally and scanned for polymorph distribution by means of confocal Raman microscopy. The $\mathrm{pH}_{\mathrm{low}}$-shells displayed a twofold increase in aragonite area fraction and size-normalised aragonite area. Size-normalised calcite area was halved in $\mathrm{pH}_{\text {low }}$ shells. Taken together with the increased apical and the decreased flank size-normalised thickness of the $\mathrm{pH}_{\text {low }}$ shells, these data led us to conclude that low-pH-exposed $P$. caerulea specimens counteract shell dissolution by enhanced shell production. This is different from normal elongation growth and proceeds through addition of aragonitic parts only, while the production of calcitic parts is confined to elongation growth. Therefore, aragonite cannot be regarded as a disadvantageous polymorph per se under ocean acidification conditions.
\end{abstract}

\section{Introduction}

There is general consensus that anthropogenic $\mathrm{CO}_{2}$ emissions lead to decreasing surface ocean $\mathrm{pH}$ and carbonate ion concentration, a process termed ocean acidification (e.g. Royal Society, 2005). This entails a decrease in seawater saturation state with respect to calcium carbonate. Calcium carbonates occur in the form of different polymorphs, the most resistant to dissolution being calcite, followed by aragonite. It was proposed that by the year 2100 the subarctic Pacific
Ocean and the entire Southern Ocean will be under-saturated with respect to aragonite (Orr et al., 2005). Wintertime aragonite under-saturation in the Southern Ocean may even occur as early as 2030 (McNeil and Matear, 2008). Since many marine organisms use aragonite or calcite to build their shells, there have been concerns regarding the vulnerability of these organisms to ocean acidification. The fact that aragonite is more soluble than calcite has led to the widely held notion that aragonite producers are more vulnerable to ocean acidification than calcite producers (Field et al., 2011; Gattuso and Hansson, 2011; Royal Society, 2005). The extreme sensitivity of aragonitic pteropods to dissolution (Bednarsek et al., 2012) seems to support this view. Some molluscs, e.g. patellogastropod limpets and the Littorinidae (Hedegaard et al., 1997; Taylor and Reid, 1990), have, in addition to aragonitic shell layers, evolved outer calcitic shell layers. It was argued that calcitic shell layers are an adaptation to resist dissolution (Taylor and Reid, 1990). This hypothesis was questioned on the basis of a comparative dissolution study using aragonitic and calcitic bivalve microstructures (Harper, 2000). Comparing the post-mortem dissolution rates of four (two aragonitic and two calcitic) Antarctic benthic species, McClintock et al. (2009) supported the conclusion of Harper (2000). These two studies imply the notion that dissolution of calcium carbonate biominerals is not primarily a question of the polymorph, but depends largely on composition and microstructure of the biomineral. As regards the vulnerability to ocean acidification, shell dissolution is merely one aspect, which focuses entirely on the product, i.e. the shell. The production of the shell is another aspect, and 
under ocean acidification some organisms might be able to compensate for shell dissolution by increasing shell production (Rodolfo-Metalpa et al., 2011). This compensatory shell production might favour the more dissolution-resistant polymorph in species producing both aragonite and calcite (see also Taylor and Reid, 1990). Specimens of the limpet Patella caerulea, collected at an acidified volcanic $\mathrm{CO}_{2}$ vent site at Ischia, displayed higher gross calcification rates than their fellow specimens, collected outside the vent site (normal $\mathrm{pH}$, Rodolfo-Metalpa et al., 2011). It was also shown that $P$. caerulea specimens collected within the vent site are considerably corroded (Hall-Spencer et al., 2008; RodolfoMetalpa et al., 2011). Taken together, the previous two observations suggest that $P$. caerulea might be able to compensate, to a certain extent (compare Hall-Spencer et al., 2008; Rodolfo-Metalpa et al., 2011), shell dissolution by increased shell production. Since limpets produce aragonitic as well as calcitic shell layers (see above), an interesting question is whether compensatory shell production shows a bias towards a particular polymorph. Here we present the polymorph distribution of complete cross sections of $P$. caerulea shells collected from within and outside the Ischia $\mathrm{CO}_{2}$ vent site.

\section{Material and methods}

\subsection{Study site and sampling}

The study site is an area located off the east coast of Ischia $\left(40^{\circ} 43.81^{\prime} \mathrm{N}, 13^{\circ} 57.98^{\prime} \mathrm{E}\right)$, in shallow waters of $2-6 \mathrm{~m}$ and within $1-15 \mathrm{~m}$ of the shore line. Emissions from the vents in this area are composed of $90-95 \% \mathrm{CO}_{2}, 3-6 \% \mathrm{~N}_{2}, 0.6-$ $0.8 \% \mathrm{O}_{2}, 0.2-0.8 \% \mathrm{CH}_{4}$ and $0.08-0.1 \% \mathrm{Ar}$, without toxic sulphur compounds (Hall-Spencer et al., 2008). Since the vent gases do not contain toxic substances and are at ambient seawater temperature, this area can be used as a natural laboratory to understand ecosystem effects of ocean acidification. Gas fluxes were measured during 2006-2007, and no seasonal, tidal or diurnal variation in gas flow rates was detected, while $\mathrm{pH}$ and saturation states of aragonite and calcite varied with sea state, being lowest on calm days, and showed large decreases as $p \mathrm{CO}_{2}$ amounts increased proceeding towards the vent sites (Hall-Spencer et al., 2008). Patella caerulea specimens were collected from two low-pH sites (PL1 and PL2), and from a control site (C) in December 2009 (Fig. 1). Temperature, $\mathrm{pH}$ and TA were measured from September to December 2009, and the other carbonate chemistry parameters were calculated from them. PL1 and PL2 had a mean $\mathrm{pH}$ of $6.46 \pm 0.35$ (mean $\pm \mathrm{SD}$ ) and $6.51 \pm 0.38$ respectively, while the control site had a mean $\mathrm{pH}$ of $8.03 \pm 0.05$ (Table 1).

\subsection{Sample preparation and Raman spectroscopy}

Raman imaging was done using a WITec alpha $300 \mathrm{R}$ (WITec GmbH, Germany) confocal Raman microscope. Imaging was done using a motorised scan table with a max-

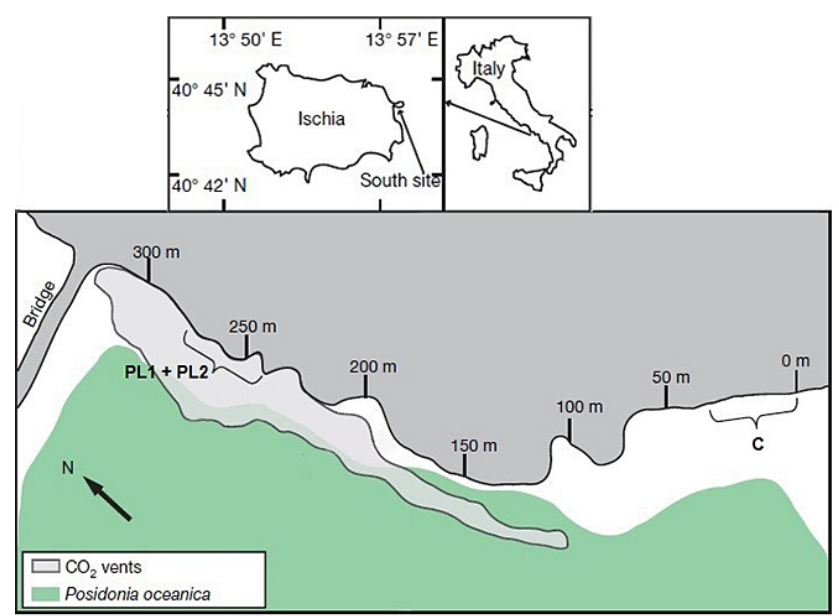

Figure 1. Study area, showing the low-pH sites (PL1 and PL2) and the control site $(\mathrm{C})$.

imum scan range of up to $2.5 \mathrm{~cm} \times 2.5 \mathrm{~cm}$ and a minimum step size of $100 \mathrm{~nm}$. Scans are performed using a $532 \mathrm{~nm}$ diode laser and an ultra-high throughput spectrometer with a grating, $600 \mathrm{~mm}$ and $500 \mathrm{~mm}$ blaze (UHTS 300, WITec, Germany). The objective used was a $20 \times$ Zeiss with a NA of 0.4 .

For the imaging, every $10 \mu \mathrm{m}$ a Raman spectra was acquired with a integration time of $0.05 \mathrm{~s}$ per spectra. The size of the sample and its irregular shape as well as the extremely high resolution of $10 \mu \mathrm{m}$ (resulting in huge spectral files) did not allow imaging the whole sample in one run. Therefore, the sample had to be repositioned several times. The sample processing was done for each scan separately (using the WITec Project software, version 2.10). This resulted in slightly different colour scales for each image, since it was not possible to synchronise these scales during the data processing. However, this only alters the optical appearance of the images after they have been stitched together using the software Gimp 2.8 and does not affect the interpretation of the images. For details on the Raman imaging of this type of samples the interested reader is referred to several other studies performed using the described setup (e.g. Nehrke and Nouet, 2011; Nehrke et al., 2012; Wall and Nehrke, 2012; Stemmer and Nehrke, 2014).

\subsection{Size measurements and data analysis}

Transversally sectioned and resin-embedded shells were imaged using a Nikon SMZ1500 stereo microscope. Shell length and shell thickness were measured using Nikon NIS Elements 4.0 software. All bar plots show the mean \pm SD of four shells (four $\mathrm{pH}_{\text {low }}$-shells and four $\mathrm{pH}_{\mathrm{n}}$-shells were analysed). Since shells of $P$. caerulea are not symmetric we always measured the shorter of the two shell flanks. Size-normalised thickness of a shell's shorter flank (SNTF) was determined by averaging ca. 35 evenly spaced thickness 
Table 1. Mean value $\left( \pm \mathrm{SD}\right.$ ) of temperature $(T), \mathrm{pH}_{\mathrm{T}}$ (total scale), $p \mathrm{CO}_{2}$, concentration of $\mathrm{HCO}_{3}^{-}$and $\mathrm{CO}_{3}^{2-}$ ions, $\mathrm{CO}_{2}$ concentration in sea water, dissolved inorganic carbon (DIC), saturation state $(\Omega)$ of aragonite and calcite for the study sites.

\begin{tabular}{|c|c|c|c|c|c|c|c|c|c|}
\hline \multirow[t]{2}{*}{ Site } & $T$ & $\mathrm{pH}_{\mathrm{T}}$ & $p \mathrm{CO}_{2}$ & $\mathrm{HCO}_{3}^{-}$ & $\mathrm{CO}_{3}^{2-}$ & $\mathrm{CO}_{2}$ & DIC & \multirow[t]{2}{*}{$\Omega_{\mathrm{Ca}}$} & \multirow[t]{2}{*}{$\Omega_{\mathrm{Ar}}$} \\
\hline & $\left({ }^{\circ} \mathrm{C}\right)$ & & ( $\mu \mathrm{atm})$ & \multicolumn{4}{|c|}{$\left(\mu \mathrm{mol} \mathrm{kg}{ }^{-1}\right)$} & & \\
\hline $\mathrm{C}$ & $\begin{array}{c}19.7 \\
( \pm 2.0)\end{array}$ & $\begin{array}{c}8.03 \\
( \pm 0.05)\end{array}$ & $\begin{array}{c}474 \\
( \pm 74)\end{array}$ & $\begin{array}{c}2043 \\
( \pm 46)\end{array}$ & $\begin{array}{c}220 \\
( \pm 19)\end{array}$ & $\begin{array}{c}15 \\
( \pm 2)\end{array}$ & $\begin{array}{c}2279 \\
( \pm 29)\end{array}$ & $\begin{array}{c}5.15 \\
( \pm 0.45)\end{array}$ & $\begin{array}{c}3.36 \\
( \pm 0.30)\end{array}$ \\
\hline PL1 & $\begin{array}{c}20.1 \\
( \pm 2.2)\end{array}$ & $\begin{array}{c}6.46 \\
( \pm 0.35)\end{array}$ & $\begin{array}{c}22047 \\
( \pm 13264)\end{array}$ & $\begin{array}{c}2542 \\
( \pm 50)\end{array}$ & $\begin{array}{c}14 \\
( \pm 21)\end{array}$ & $\begin{array}{c}758 \\
( \pm 510)\end{array}$ & $\begin{array}{c}3315 \\
( \pm 526)\end{array}$ & $\begin{array}{c}0.33 \\
( \pm 0.48)\end{array}$ & $\begin{array}{c}0.22 \\
( \pm 0.32)\end{array}$ \\
\hline PL2 & $\begin{array}{c}20.1 \\
( \pm 2.2)\end{array}$ & $\begin{array}{c}6.51 \\
( \pm 0.38)\end{array}$ & $\begin{array}{c}19504 \\
( \pm 12338)\end{array}$ & $\begin{array}{c}2509 \\
( \pm 96)\end{array}$ & $\begin{array}{c}17 \\
( \pm 18)\end{array}$ & $\begin{array}{c}618 \\
( \pm 392)\end{array}$ & $\begin{array}{c}3143 \\
( \pm 426)\end{array}$ & $\begin{array}{c}0.39 \\
( \pm 0.43)\end{array}$ & $\begin{array}{c}0.26 \\
( \pm 0.28)\end{array}$ \\
\hline
\end{tabular}

measurements and dividing the resulting values by the shell's length. Size-normalised thickness of a shell's apex (SNTA) was determined by averaging ca. 10 evenly spaced thickness measurements and dividing the resulting value by the shell's length. The apex of a shell was arbitrarily defined as a certain distance (ca. $1.5 \mathrm{~mm}$ ) left and right to the highest point of the shell (see Fig. 2). The latter measure was taken to avoid a one-point measurement of the highest point of a shell. Such a one-point measurement is prone to being not representative. The fraction of aragonite area (FA) was determined as pixels representing aragonite (measured by means of Nikon NIS Elements 4.0 software) divided by the sum of pixels representing aragonite and pixels representing calcite (Fig. 3). The size-normalised aragonite area (SNAA) equals pixels representing aragonite divided by the shell length. The size-normalised calcite area (SNCA) equals pixels representing calcite divided by the shell length.

\section{Results}

All shells selected for analysis were of similar size. The length of the $\mathrm{pH}_{\mathrm{n}}$-shells was $31 \pm 2 \mathrm{~mm}$ (mean $\pm \mathrm{SD}$ of four shells), while the length of the $\mathrm{pH}_{\text {low }}$-shells was $36 \pm 3 \mathrm{~mm}$ (mean \pm SD of four shells). Polymorph distribution imaging revealed marked differences between $\mathrm{pH}_{\text {low }}$-shells and $\mathrm{pH}_{\mathrm{n}}$-shells (Fig. 4). Size-normalised thickness of the flank (SNTF) was $26 \%$ lower in $\mathrm{pH}_{\text {low }}$-shells (Fig. 5), while sizenormalised thickness of the apex (SNTA) was $26 \%$ higher in $\mathrm{pH}_{\text {low }}$-shells (Fig. 6). The fraction of aragonite area (FA) was by a factor of 2.3 higher in $\mathrm{pH}_{\mathrm{low}}$-shells (Fig. 7). Sizenormalised aragonite area (SNAA) was by a factor of 2.2 higher in $\mathrm{pH}_{\text {low }}$-shells (Fig. 8), and size-normalised calcite area (SNCA) was by a factor of 2.4 lower in $\mathrm{pH}_{\text {low }}$-shells (Fig. 9).

\section{Discussion}

The low-pH site at Ischia, from which the analysed $\mathrm{pH}_{\text {low }}-$ shells were taken, features seawater that is under-saturated

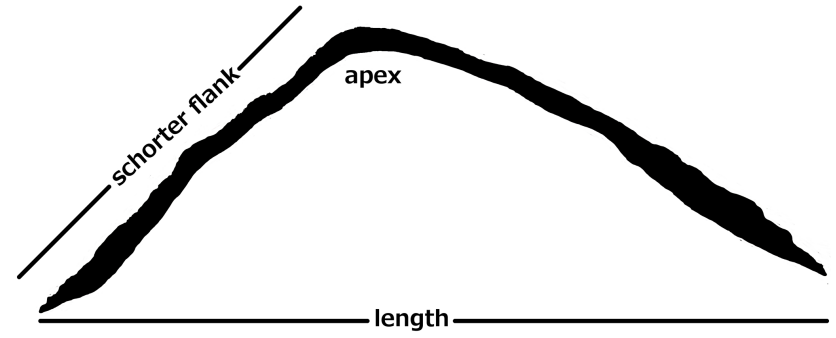

Figure 2. Sketch of a shell indicating length, apex, and shortest flank.

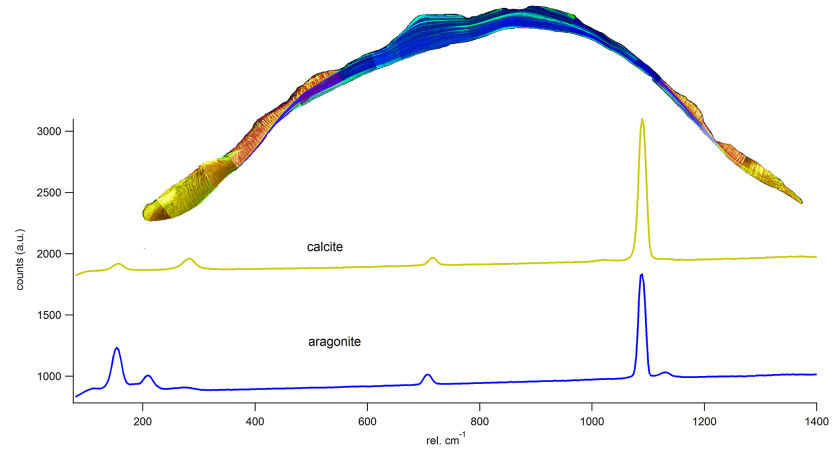

Figure 3. Example of a Raman image across the cross section of the shell. Blue represents aragonite and yellow calcite, as identified by the corresponding Raman spectra shown.

with respect to both aragonite and calcite (Table 1). Hence, shells of calcareous organisms residing in these undersaturated waters are prone to dissolution. Indeed, shells of $P$. caerulea clearly show signs of dissolution (HallSpencer et al., 2008; Rodolfo-Metalpa et al., 2011). Therefore, $P$. caerulea $\mathrm{pH}_{\text {low }}$-shells are the product of both shell formation and dissolution, as opposed to $\mathrm{N}$-shells (originating from the normal $\mathrm{pH}$ site), which are merely the product of shell formation. Provided they grow normally, $\mathrm{pH}_{\text {low }}-$ shells should, because of dissolution, display a reduced sizenormalised thickness (SNT). This is, for the flank area of the 


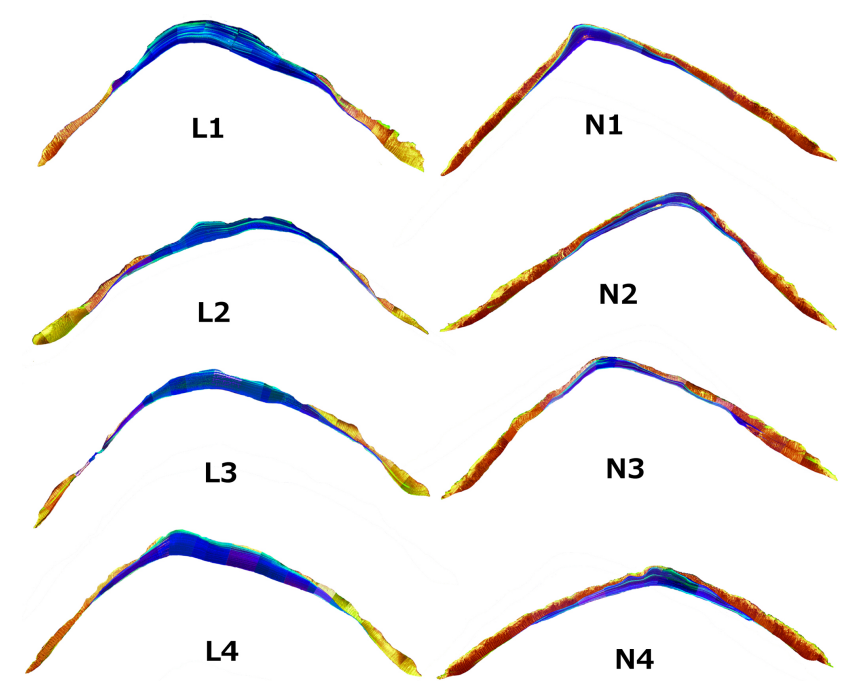

Figure 4. Polymorph distribution of transversally sectioned shells. Blue $=$ aragonite,$\quad$ yellow $=$ calcite. $\quad$ Normal $=\mathrm{pH}_{\mathrm{n}}$-shells, low $=\mathrm{pH}_{\text {low }}$-shells.

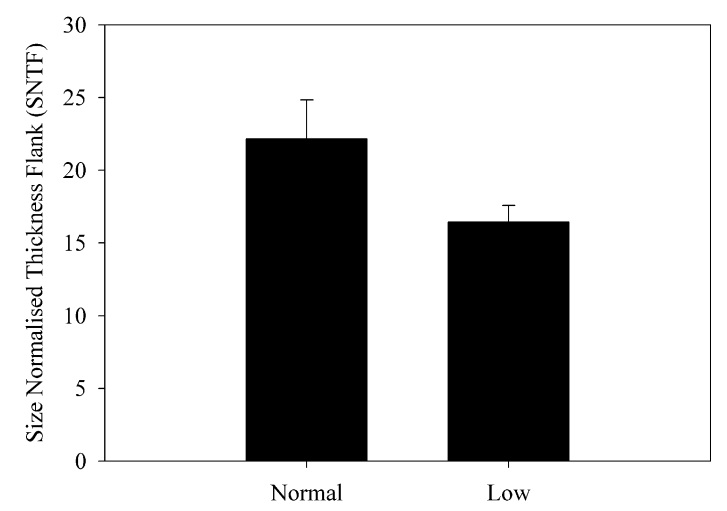

Figure 5. Size-normalised thickness of the flank (SNTF). Normal $=\mathrm{pH}_{\mathrm{n}}$-shells, low $=\mathrm{pH}_{\text {low }}$-shells.

shell, indeed the case (Fig. 7). On the contrary, in the apex area, the $\mathrm{SNT}$ is higher in $\mathrm{pH}_{\mathrm{low}}$-shells (Fig. 6). The latter can only stem from enhanced shell production. From the above it can be concluded that net shell production in $\mathrm{pH}_{\text {low }}$-shells is region specific, i.e. enhanced at the apex area, and reduced along the flank area. A comparison of the mineralogical composition of the shells from the two different sites shows that the fraction of aragonite area (FA) for $\mathrm{pH}_{\text {low-shells is twice }}$ as big as for $\mathrm{pH}_{\mathrm{n}}$-shells (Fig. 7). This observation could exclusively be due to a higher SNT of the apex area, which is predominantly aragonitic. If the increased FA is related to normal shell production and dissolution, the size-normalised aragonite area (SNAA) should be unaltered or decreased. We observed, contrariwise, an increased SNAA (Fig. 8), which is in line with the increased SNT of the apex area, both pointing to enhanced shell production. Along the flank area, however, the SNT is decreased in $\mathrm{pH}_{\text {low }}$-shells (Fig. 7), and so is

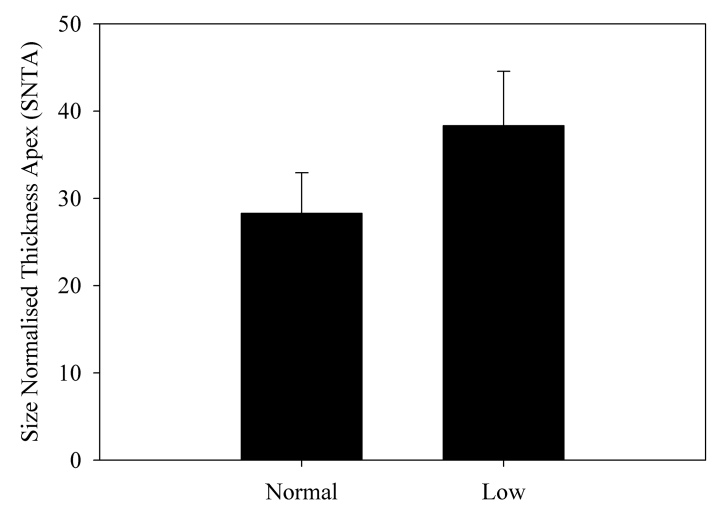

Figure 6. Size-normalised thickness of the apex (SNTA). Normal $=\mathrm{pH}_{\mathrm{n}}$-shells, low $=\mathrm{pH}_{\text {low }}$-shells.

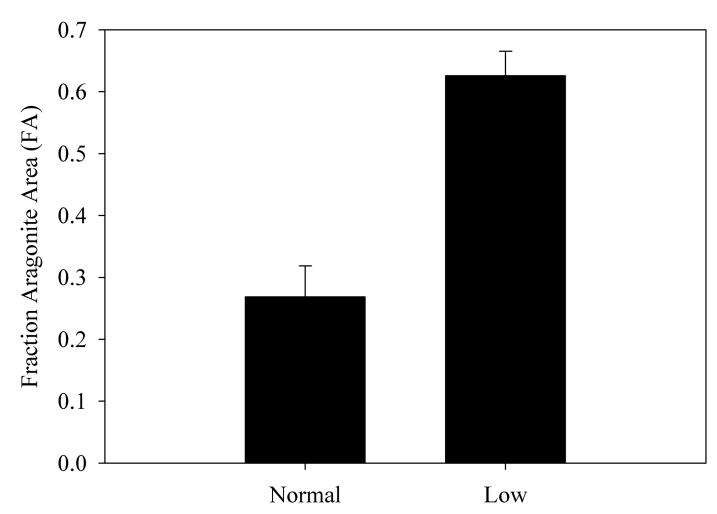

Figure 7. Fraction of aragonite area (FA). Normal $=\mathrm{pH}_{\mathrm{n}}$-shells, low $=\mathrm{pH}_{\text {low }}$-shells.

the overall size-normalised calcite area (SNCA, Fig. 9). To conclude, there is ample evidence suggesting that low-pHexposed $P$. caerulea specimens counteract dissolution by enhanced shell production. Hence, the mineralogical analyses of the shell sections support our conclusion drawn on the basis of the thickness measurements, i.e. that enhancement of shell production is region specific, and, by entailment, polymorph specific. The latter conclusion is plausible when considering simultaneous shell growth and dissolution as will be detailed in the following.

Under normal $\mathrm{pH}$ conditions, $P$. caerulea produces shells characterised by a predominately aragonitic apex area and a flank area which is aragonitic and calcitic in the upper part, but solely calcitic in the lower part. This is different for shells formed under low-pH conditions. The apex area is still predominantly aragonitic but large parts of the flank area are now aragonitic as well (compare Fig. 4). This observation is related to the fact that shell growth and dissolution take place simultaneously during the complete lifespan of $P$. caerulea. Under normal $\mathrm{pH}$ conditions, the shell is growing by the addition of calcitic material at the edges of the shell flank in the form of a cross-foliated structure (MacClintock, 1967). 


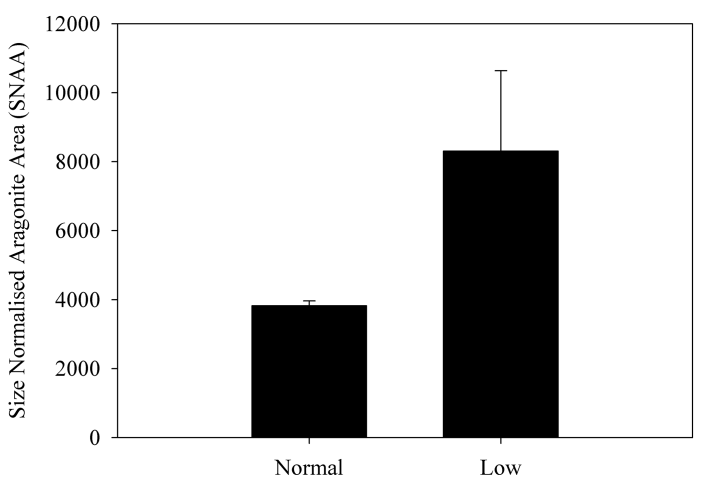

Figure 8. Size-normalised aragonite area (SNAA). Normal $=\mathrm{pH}_{\mathrm{n}}$ shells, low $=\mathrm{pH}_{\text {low }}$-shells.

With time this material is dissolved which results in a thinning of the shell. Our observations suggest that $P$. caerulea counteracts this thinning by depositing additional layers on the inner side of the shell. Since the deposition of layers at the inner side of the shell is related to a mechanism producing aragonite the amount of aragonite increases while calcitic parts at the outside are dissolved. New formation of calcitic areas is only possible during elongation of the shell (increase in size) but not to counteract dissolution. The scenario described above results in the relative (as expressed by FA, Fig. 7) increase in aragonite in the $\mathrm{pH}_{\mathrm{low}}$-shells. Taken together with the absolute (as expressed by SNAA, Fig. 8) increase in aragonite and the increased SNT of the apex area (Fig. 6) in the $\mathrm{pH}_{\text {low-shells, this suggests a high efficacy }}$ of the compensatory shell production. Our results demonstrate that the ability of limpets to cope, to a certain extent (compare also Hall-Spencer et al., 2008; Rodolfo-Metalpa et al., 2011), with corrosive waters is not related to the preferential usage of the more dissolution-resistant polymorph, but is solely governed by the mechanism of shell formation. This mechanism allows for compensatory shell thickening through the deposition of additional layers on the inner side of the shell. We do not know whether the additional layers are structural layers.

One possibility is that the layers we call "additional" are similar to the layers related to shell repair in Haliotis (Fleury et al., 2008). These additional layers are aragonitic, but this is genetically determined and does not represent a response to ocean acidification. The shift towards aragonite seen in $\mathrm{pH}_{\text {low }}$-shells is simply a by-product of the way limpets use calcium carbonate polymorphs in shell formation. The fact that the additional, aragonitic layers of the $\mathrm{pH}_{\text {low }}$-shells lead to an increased SNT of the apex (Fig. 6) also shows that aragonite cannot be regarded as a disadvantageous polymorph per se under corrosive ocean acidification. We ascribed the changes in shell mineralogy and shell thickness of our samples to seawater carbonate chemistry changes. Since these are field samples, as opposed to experimental samples, possible secondary influences have to be considered. For Mytilus

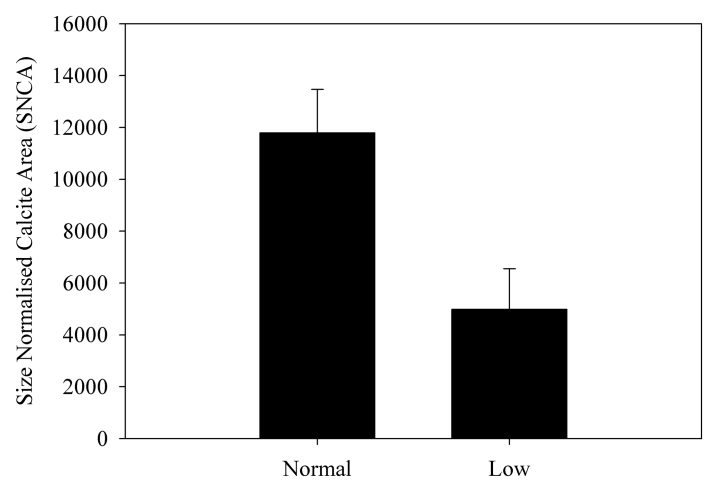

Figure 9. Size-normalised calcite area (SNCA). Normal $=\mathrm{pH}_{\mathrm{n}^{-}}$ shells, low $=\mathrm{pH}_{\text {low }}$-shells.

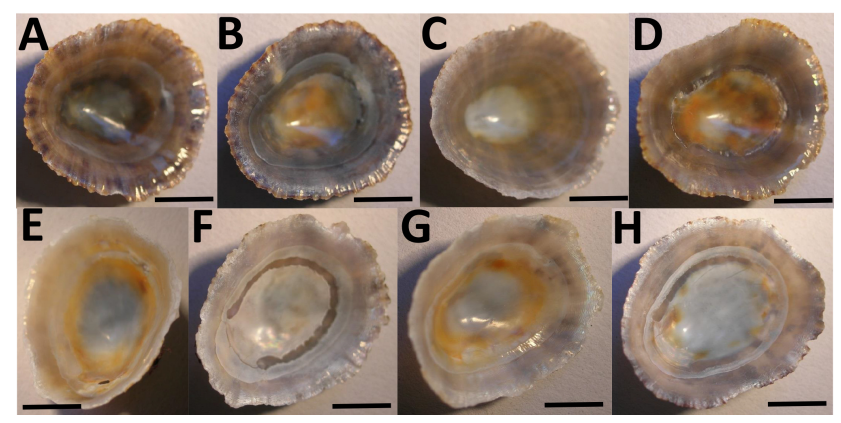

Figure 10. Photographs of the analysed shells. Shells sampled at the control site, i.e. at normal $\mathrm{pH}$ (a-d). Shells sampled at the vent site, i.e. at low $\mathrm{pH}$ (e-h).

it was shown that maybe salinity but certainly temperature influences the aragonite/calcite ratio (Dodd, 1966; Eisma, 1966). The latter is also true for Patella (Cohen and Branch, 1992). In our case, however, both temperature and salinity at the two sites (Fig. 1) were the same at any given time (Table 1, Cigliano et al., 2010; Hall-Spencer et al., 2008; Rodolfo-Metalpa et al., 2011), and we conclude that these two parameters did not influence the aragonite / calcite ratio of our samples. Also, both the control site and the low-pH site we sampled at Ischia are sheltered so that there is no difference in wave action, which could potentially influence shell architecture. Furthermore, it was suggested that the concentrations of inorganic ions such as $\mathrm{Mg}$ and $\mathrm{Sr}$ can influence the mineralogy of marine calcifying organisms (Watabe, 1974). Since salinity was constant in our case, the concentrations of major ions such as $\mathrm{Mg}$ and $\mathrm{Sr}$ were also constant, and their influence can be ruled out. On the other hand, shells from the low-pH site clearly are corroded (see above, and Fig. 10), so there is a massive impact of seawater carbonate chemistry on the organism. Taken together with the constancy of other environmental parameters, this leads us to conclude that carbonate chemistry changes are the best explanation for the changes in shell mineralogy and shell thickness of our samples. 


\section{Conclusions}

Polymorph distribution analyses of complete cross sections of Patella caerulea shells from a $\mathrm{CO}_{2}$ vent site at Ischia revealed that this species counteracts shell dissolution in corrosive waters by enhanced production of aragonitic shell layers. The question of whether these layers represent structural layers will be the subject matter of an upcoming microstructural investigation.

Acknowledgements. This work was funded by The European Research Council (ERC grant 2010-NEWLOG ADG-267931 HE). This work contributes to the EU "Mediterranean Sea Acidification under a changing climate" project (MedSeA; grant agreement 265103) and the NERC UK Ocean Acidification Research Programme (grant no. NE/H02543X/1).

Edited by: A. Shemesh

\section{References}

Bednarsek, N., Tarling, G. A., Bakker, D. C. E., Fielding, S., Jones, E. M., Venables, H. J., Ward, P., Kuzirian, A., Leze, B., Feely, R. A., and Murphy, E. J.: Extensive dissolution of live pteropods in the Southern Ocean, Nat. Geosci., 5, 881-885, 2012.

Cigliano, M., Gambi, M. C., Rodolfo-Metalpa, R., Patti, F. P., and Hall-Spencer, J. M.: Effects of ocean acidification on invertebrate settlement at volcanic $\mathrm{CO}_{2}$ vents, Mar. Biol., 157, 2489-2502, 2010.

Cohen, A. L. and Branch, G. M.: Environmentally controlled variation in the structure and mineralogy of Patella granularis shells from the coast of southern Africa: implications for palaeotemperature assessments, Palaeogeogr, Palaeocl., 91, 49-57, 1992.

Dodd, J. R.: The Influence of Salinity on Mollusk Shell Mineralogy: A Discussion, J. Geol., 74, 85-89, 1966.

Eisma, D.: The Influence of Salinity on Mollusk Shell Mineralogy: A Discussion, J. Geol., 74, 89-94, 1966.

Field, C. B., Barros, V., Stocker, T. F., Dahe, Q., Mach, K. J., Plattner, G., Mastrandrea, M. D., Tignor, M., and Ebi, K. L.: IPCC Workshop on Impacts of Ocean Acidification on Marine Biology and Ecosystems, 17-19 January 2011, Carnegie Institution, Stanford, California, USA, 164 pp., 2011.

Fleury, C., Marin, F., Marie, B., Luquet, G., Thomas, J., Josse, C., Serpentini, A., and Lebel, J. M.: Shell repair process in the green ormer Haliotis tuberculata: A histological and microstructural study, Tissue and Cell, 40, 207-218, 2008.

Gattuso, J.-P. and Hansson, L.: Ocean Acidification, Oxford University Press, Oxford, UK, 2011.

Hall-Spencer, J. M., Rodolfo-Metalpa, R., Martin, S., Ransome, E., Fine, M., Turner, S. M., Rowley, S. J., Tedesco, D., and Buia, M.-C.: Volcanic carbon dioxide vents show ecosystem effects of ocean acidification, Nature, 454, 96-99, 2008

Harper, E. M.: Are calcitic layers an effective adaptation against shell dissolution in the Bivalvia?, J. Zool., 251, 179-186, 2000.

Hedegaard, C., Lindberg, D. R., and Bandel, K.: Shell microstructure of a Triassic patellogastropod limpet, Lethaia, 30, 331-335, 1997.
MacClintock, C.: Shell Structure of Patelloid and Bellerophontoid Gastropods (Mollusca), Peabody Museum of Natural History Yale University Bulletin, 22, 140 pp., New Haven, Connecticut, 1967.

McClintock, J. B., Angus, R. A., Mcdonald, M. R., Amsler, C. D., Catledge, S. A., and Vohra, Y. K.: Rapid dissolution of shells of weakly calcified Antarctic benthic macroorganisms indicates high vulnerability to ocean acidification, Antarct. Sci., 21, 449456, 2009

McNeil, B. I. and Matear, R. J.: Southern Ocean acidification: a tipping point at $450-$ ppm atmospheric $\mathrm{CO}_{2}$, P. Natl. Acad. Sci. USA, 105, 18860-18864, 2008.

Nehrke, G. and Nouet, J.: Confocal Raman microscope mapping as a tool to describe different mineral and organic phases at high spatial resolution within marine biogenic carbonates: case study on Nerita undata (Gastropoda, Neritopsina), Biogeosciences, 8 , 3761-3769, doi:10.5194/bg-8-3761-2011, 2011.

Nehrke, G., Poigner, H., Wilhelms-Dick, D., Brey, T., and Abele, D.: Coexistence of three calcium carbonate polymorphs in the shell of the Antarctic clam Laternula elliptica, Geochem. Geophy. Geosy., 13, Q05014, doi:10.1029/2011GC003996, 2012.

Orr, J. C., Fabry, V. J., Aumont, O., Bopp, L., Doney, S. C., Feely, R. A., Gnanadesikan, A., Gruber, N., Ishida, A., Joos, F., Key, R. M., Lindsay, K., Maier-Reimer, E., Matear, R., Monfray, P., Mouchet, A., Najjar, R. G., Plattner, G.-K., Rodgers, K. B., Sabine, C. L., Sarmiento, J. L., Schlitzer, R., Slater, R. D., Totterdell, I. J., Weirig, M.-F., Yamanaka, Y., and Yool, A.: Anthropogenic ocean acidification over the twenty-first century and its impact on calcifying organisms, Nature, 437, 681-686, 2005.

Rodolfo-Metalpa, R., Houlbreque, F., Tambutte, E., Boisson, F., Baggini, C., Patti, F. P., Jeffree, R., Fine, M., Foggo, A., Gattuso, J.-P., and Hall-Spencer, J. M.: Coral and mollusc resistance to ocean acidification adversely affected by warming, Nature Climate Change, 1, 308-312, 2011.

Royal Society: Ocean Acidification due to Increasing Atmospheric Carbon Dioxide, Policy Document 12/05, The Royal Society, London, 60 pp., 2005.

Stemmer, K. and Nehrke G.: The distribution of polyenes in the shell of Arctica islandica from North Atlantic localities: a confocal Raman microscopy study, J. Mollus. Stud., 80, 365-370, doi:10.1093/molus/eyu033, 2014.

Taylor, J. D. and Reid, D. G.: Shell microstructure and mineralogy of the Littorinidae: ecological and evolutionary significance, Hydrobiologia, 193, 199-215, 1990.

Wall, M. and Nehrke, G.: Reconstructing skeletal fiber arrangement and growth mode in the coral Porites lutea (Cnidaria, Scleractinia): a confocal Raman microscopy study, Biogeosciences, 9, 4885-4895, doi:10.5194/bg-9-4885-2012, 2012.

Watabe, N.: Crystal growth of calcium carbonate in biological systems, J. Cryst. Growth, 24-25, 116-122, 1974. 